\title{
Correlation between the Diversity and Land Use in Cleared Grassland Areas in the Pannon Mountains
}

\author{
Zsófia Fehér ${ }^{1}$, Sándor Hajnáczki ${ }^{1}$, Péter Penksza ${ }^{2}$, Péter Szőke ${ }^{1}$, Károly Penksza $^{1}$ and Barnabás Wichmann ${ }^{1}$ \\ 1. Institute of Botany and Ecophysiology, Szent István University, Gödöllö Hu 2103, Hungary \\ 2. Department of Food Preservation, Corvinus University, Budapest Hu 1118, Hungary
}

Received: January 15, 2015 / Accepted: January 25, 2015 / Published: February 25, 2015.

\begin{abstract}
Nowadays, mowing has an increasing role in the management of semi-natural and nature conservation areas. Semi-dry grasslands have been planted on cleared areas of forest in the Pannon Mountains, which would be reclaimed by forest without use of the areas by humans. In our work we analysed cleared grasslands. The questions we tried to answer were which changes were caused by different land use, how favourable mowing can be for the purpose of grassland management and nature protection, do the composition of the plant species and the diversity vary within two years when conditions of precipitation are different. In four sampling areas, in $4 \times 10$ quadrats we registered the plant species and their cover values. We performed a site assessment in April, June and October, 2013-2014. We analysed the data by using cluster and ordination processes and we compared the sampling areas on the basis of the humidity preference and Shannon's index of diversity. According to the results, the composition of species and diversity on the analysed areas used for different purposes considerably deviate from each other. Further, we found a difference between two portions of the area whose had minor deviation in water management.
\end{abstract}

Key words: Mowing, land use, diversity.

\section{Introduction}

Areas of natural grasslands have considerably decreased in Europe in the past decades [1-11], while priority has been given to grassland management using nature conservation and ecological criteria [12, 13]. The reason that conservation of grasslands is highly important in maintaining and preserving the diversity of biology [14].

Natural and semi-natural grasslands are also endangered by the loss of habitats and by industrial and recreational activities $[15,16]$. Due to changed land use, traditionally managed grasslands are rarely seen [17]. This is an unfortunate fact as regular mowing and maintaining these grasslands as pasture are the primary means of maintaining these areas, which are of high importance in terms of nature conservation management, by effecting the successive

Corresponding author: Zsófia Fehér, Ph.D student, research fields: plant ecology and vegetation science. E-mail: feherzsofia@invitel.hu. processes [18-21].

Natural disturbances form part of the ecological systems, and the majority of meadows and hayfields of high nature conservation value can only be preserved by treatment $[22,23]$. By means of nature conservation treatments, the number of species on grasslands can be increased and various accompanying species can be planted [24-29].

Besides, due to the removal of the accumulated leaf-mould, colonization patches are created for numerous accompanying dicotyledonous species [30, 31]. The extensive grassland management, the preservation of nature conservation areas and the flora and fauna are also supported by the NATURA 2000 network through the supporting system of the European Union [32].

In our work we analysed various hayed grasslands. We looked for the answer to the question which changes were caused on the areas by the different land use, do the composition of the plant species and the 
diversity vary within two years when conditions of precipitation are different.

\section{Materials and Methods}

\subsection{The Surveyed Area}

The surveyed area is situated in the Carpathian basin, in the Northern region of Hungary, within the countryside Mount Cserhát and in the small region of Kosd hills (Fig. 1) [33]. The area was once characterised by Aceri tatarici-Quercetum roboris, Quercetalia cerris (in patches), and Salvio nemorosae-Festucetum rupicolae (in smaller patches). The meadow "Gyadai" is situated at the Northern end of Mount Naszály forming a part of the Kosd hills in the valley of the stream "Lósi", this is where our surveys were carried out.

The meadow "Gyadai" was created by cutting down the forest areas around the stream "Lósi". The largest plant communities of the meadow "Gyadai" are the meadows of Pastinaco-Arrhenatheretum and Alopecuro-Arrhenatheretum, the forest steppes and the semi-dry cleared grasslands. The meadow "Gyadai" is characterized by remnant trees, which provide shade for animals on hot days. The meadow "Gyadai" also accommodates some plant species of Carici pilosae-Carpinetum next to it $[34,35]$. The meadow is preserved by human activities (by landscaping), otherwise the entire area might be reclaimed by forest.

\subsection{The Sampling Method}

Before defining the sampling areas on the meadow "Gyadai", we made repeated visits to the site during a period of five years (3-4 times each year), when we assigned 4 parts of the grassland that were mowed regularly. We paid special attention to the areas where pressure from tourism was greater, owing to organised activities.

We used military and topographic maps as well as aerial photos to follow the changes in the history of the areas, and we also analysed detailed descriptions, written by local historical sources [36]. Based on these we established that along the stream, on the meadow "Gyadai", there was only a narrow zone of grassland (at the end of the 18th century), which was extended by the mid 19th century. From this time only minor changes of land use were carried out in the meadow. From the nineteen nineties, little patches of farmland could be seen in the area.

On the meadow "Gyadai", we assigned four sampling areas based on the records, the documents and maps and the experiences gained at the site. The four sampling areas are characterized as mowed grasslands, however due to the increasing number of visitors, the areas are more or less effected, or they may deviate from each other in the history of the landcape or in the water management parameters. The areas were mowed twice a year (in mid July and August). Random sampling was performed by quadrat

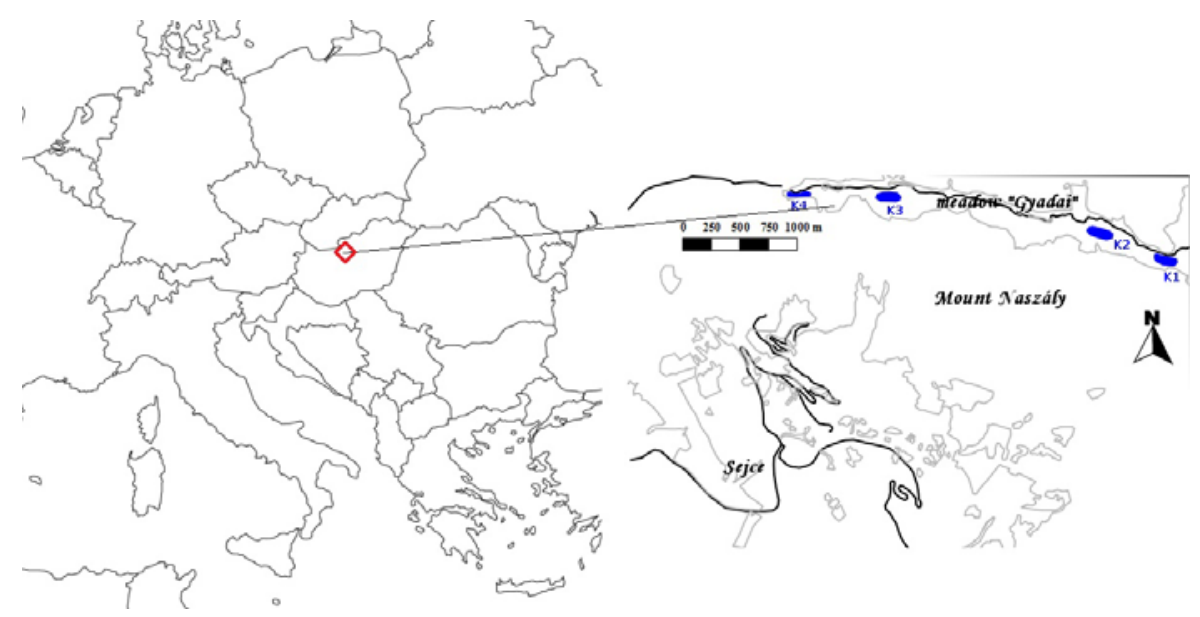

Fig. 1 Geographic situation of the surveyed area (K1-K4 = four sampling areas). 
assignment preceeding the on-site sampling. The sampling points were assigned based on a rectangular grid projected on the area, which were slightly altered by on-site corrections to avoid the quadrats falling on roads, bushes, wild boar diggings, or mud flows. Due to the random samplings it may have occurred that a quadrat had been assigned on slightly disturbed patches. We assigned a total of forty quadrats of $2 \times 2$ $\mathrm{m}$ for the coenological sampling so that 10 quadrats were assigned to each portion of the area. The quadrats with sampling codes 1-10 were assigned at a distance of approximately $2 \mathrm{kms}$ (at the possible maximum distance) from the nearby tourist information centre. Access to the area is difficult due to forest and bush areas. It cannot be accessed by car through the nearby forest, because the local forest management company has banned access to the forest road. We assigned the quadrats with sampling codes 11-20 in the area next to the above described area. In this case, however, we assumed that this area may be a dryer mowed grassland. The quadrats with sampling codes 21-30 are located in the part of the grassland near to the village "Katalinpuszta", which is a popular tourist destination with a tourist route. This part of the grassland is regularly visited by tourists. At weekends thousands of people visit the area. In 2-3 weeks, during the main plant reproduction and growth period programs are organized where 50-100 people take part, or school children play games. If there are no organised activities, people use this portion of the mowed grassland for picknicking. We assigned quadrats with sampling codes $31-40$ to be located at the beginning of the grassland, which is next to the tourist information centre. Due to its marginal conditions, this part of the grassland is not visited by tourists. The tourist route is from the tourist information centre through the forest and is next to this part of the grassland at the edge of the forest (where the slope is rising). This route is bordered by the grassland along a relatively narrow zone. The forest surrounds the narrow part of the meadow there.
Tourists typically do not leave the road to visit this side of the meadow, this is especially true for the large groups of school children, because they walk in pairs on the road under the supervision of adults until they reach the wide, open-air area mentioned above, that is the location of organised activities. It is assumed that there was a forest area in this part of the grassland 230 years ago. The sampling points were assigned three times in both surveying years. The sampling activities were carried out in the same weeks and months (April, June and October) of 2013 and 2014. We assigned the quadrats at the site by using a Garmin Dakota 20, GPS, and during further samplings we searched the fixed sample quadrats with a GPS. During sampling we recorded the time, exposure, the altitude, and the names of species according to the records produced by Király et al. [37, 38], and thus we produced an estimate of the cover values. We identified the phytocoenosis according to the literature published by Borhidi [39].

\subsection{Data Assessment}

We summarized the data of the coenologic sampling in an excel table, to which we also assigned the attributes of the database "Flóra". The data recorded in the four different sampling points were analysed for their humidity preferences [40]. The nature conservation value of some individual species of high importance covered in later analysis was also stipulated on the basis of the database "Flóra". We calculated the Shannon' diversity indexes for all the quadrats of the entire database, covering all sampling dates. We calculated the averages of the diversity indexes for each portion of area as per the date and year of sampling. Based on the average quadrat records of the portions of areas assessed on the largest covers of the relevant quadrats, we defined the dominant plant species also for each portion of the area. We regarded as plant species those species whose estimated cover exceeded $8 \%$ as per the averaged quadrats as dominant. In order to present the 
similarities and differences between the sampling points, we used the cluster analysis generated by the Bray-Curtis matrix, and the ordination process [41]. We conducted all analysis using the program R 3.02. For the purposes of data management and application, we combined the data of each species recorded in fixed quadrats, and if one of the species was found simultaneously in several various sampling points during one year, we considered the highest cover value for the calculations. We used this method of simplification instead of the averaging method, because using the averaging method, the determinant dissimilarities and the higher average cover values of the portions of areas might have disappeared. Further, this method was the best one to conform with our sampling method.

\section{Results and Discussion}

Based on the dendrogram drawn up for 2013, the area located at the beginning of the grassland (31a-40a) is strongly separated within the mowed grasslands (Fig. 2). By comparing the dendrogram with the sampling cover values, it is evident that Potentilla alba is primary and highly dominant in the above mentioned portion of the grassland. Besides, the covers of Bromus erectus, Festuca rupicola and Trisetum flavescens are considerable. The sampling quadrats (21a-30a) represent a well isolated group of species with connections to each other at low levels whose locations are often visited by tourists and where public programs are often organised. In this portion of the grassland, the primary dominant plant species is Bromus erectus whose cover is very extensive, and the secondary-dominant species are Festuca rupicola and Filipendula vulgaris. We deemed dominant plant species to be the one whose cover exceeded $8 \%$ estimated by an on-site assessment (Table 1).

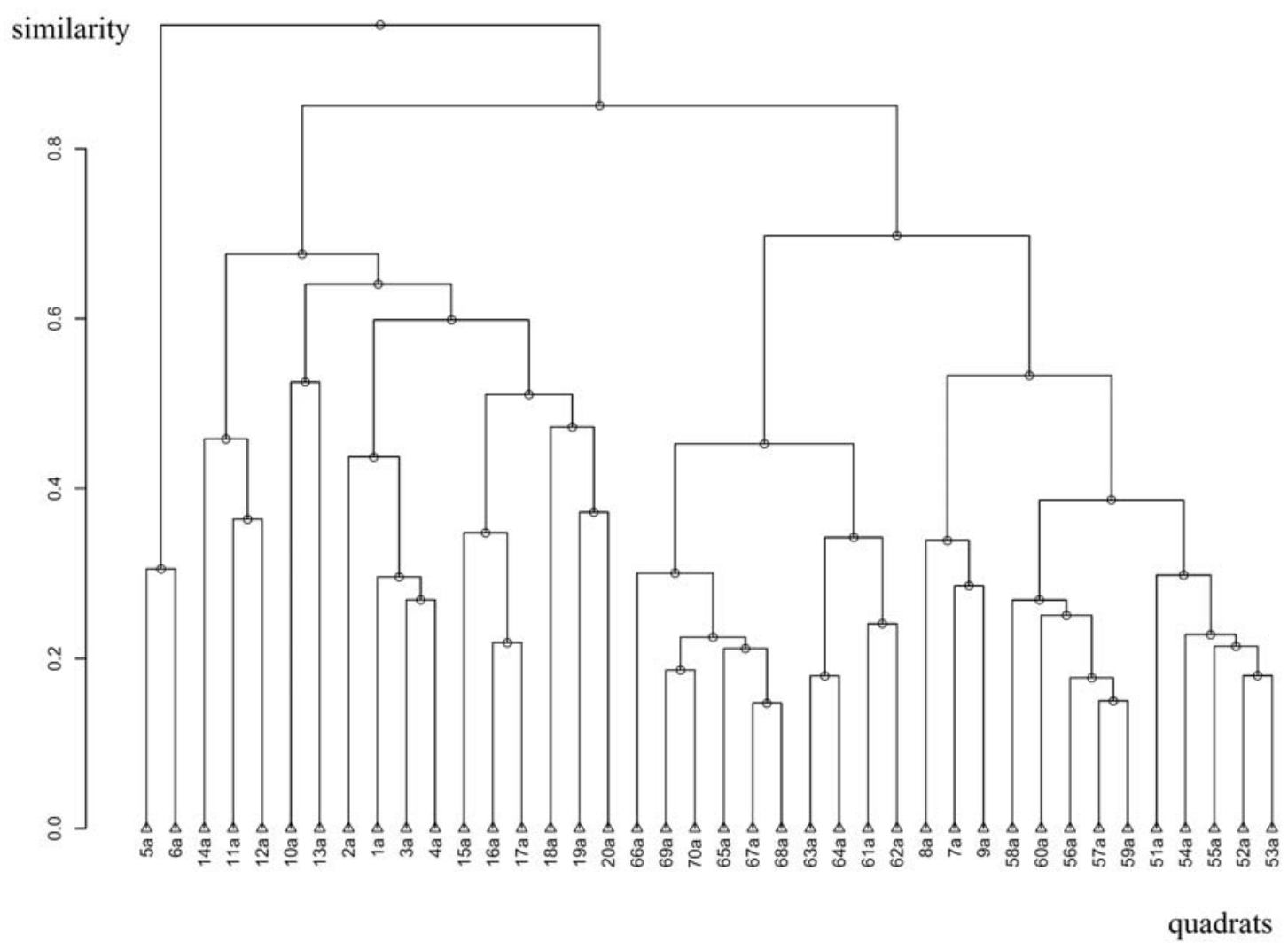

Fig. 2 Dendrogram of the sampling quadrats, 2013.

Legend: 1-10 wetter mowed meadow in the direction of Ösagárd; 11-20 dryer mowed meadow in the direction of Ösagárd; 21-30 mowed and tourist visited meadow 31-40 mowed meadow, which used to be forest; a: 2013. 
Table 1 The dominant species based on averaged quadrats of the portions of grasslands of the largest covers occurred in the relevant quadrats of the surveyed areas (2013).

\begin{tabular}{|c|c|c|c|c|c|c|c|}
\hline \multicolumn{2}{|l|}{ K1 } & \multicolumn{2}{|l|}{ K2 } & \multicolumn{2}{|l|}{$\mathrm{K} 3$} & \multicolumn{2}{|l|}{ K4 } \\
\hline Plant species & $\begin{array}{l}\text { Cover } \\
(\%)\end{array}$ & Plant species & $\begin{array}{l}\text { Cover } \\
(\%)\end{array}$ & Plant species & $\begin{array}{l}\text { Cover } \\
(\%)\end{array}$ & Plant species & $\begin{array}{l}\text { Cover } \\
(\%)\end{array}$ \\
\hline Bromus erectus & 16.9 & Festuca valesiaca & 16.1 & Bromus erectus & 46.8 & Potentilla alba & 30.5 \\
\hline Galium verum & 9.4 & Festuca rupicola & 13 & Festuca rupicola & 8.2 & Bromus erectus & 16.6 \\
\hline Festuca valesiaca & 9.3 & Galium verum & 12.1 & Filipendula vulgaris & 8.1 & Trisetum flavescens & 12 \\
\hline- & - & $\begin{array}{l}\text { Alopecurus } \\
\text { pratensis }\end{array}$ & 9.7 & - & - & Festuca rupicola & 11.2 \\
\hline
\end{tabular}

Table 2 The dominant plant species on the surveyed areas based on the averaged quadrats of the portions of area of the largest covers occurred on the relevant areas (2014).

\begin{tabular}{|c|c|c|c|c|c|c|c|}
\hline \multicolumn{2}{|l|}{ K1 } & \multicolumn{2}{|l|}{$\mathrm{K} 2$} & \multicolumn{2}{|c|}{$\mathrm{K} 3$} & \multicolumn{2}{|l|}{ K4 } \\
\hline Plant species & $\begin{array}{l}\text { Cover } \\
(\%)\end{array}$ & Plant species & $\begin{array}{l}\text { Cover } \\
(\%)\end{array}$ & Plant species & $\begin{array}{l}\text { Cover } \\
(\%)\end{array}$ & Plant species & $\begin{array}{l}\text { Cover } \\
(\%)\end{array}$ \\
\hline Bromus erectus & 22 & Trifolium campestre & 25 & Bromus erectus & 41 & Potentilla alba & 30.5 \\
\hline Trisetum flavescens & 8.9 & Carex praecox & 14 & Festuca rupicola & 12.3 & Bromus erectus & 16.6 \\
\hline Potentilla alba & 8.6 & Trifolium alpestre & 12.7 & - & - & Trisetum flavescens & 12 \\
\hline $\begin{array}{l}\text { Arrhenatherum } \\
\text { elatius }\end{array}$ & 8.4 & Trisetum flavescens & 12.5 & - & - & Festuca rupicola & 11.2 \\
\hline $\cos 2 \cos 2 \cos$ & - & Festuca valesiaca & 12.1 & - & - & $\begin{array}{l}\text { Arrhenatherum } \\
\text { elatius }\end{array}$ & 9.2 \\
\hline
\end{tabular}

The quadrats of the two mowed grasslands next to "Ösagárd" are connected to each other at a higher level, and these areas are not definitely isolated from each other. Each of the two portions of grassland are diversified, and the number of the plant species found in these two portions of grassland is much higher than in the two other portions of mowed grassland. It is worth mentioning that there are 5 dominant species: Bromus erectus, Gallium verum, Festuca valesiaca, Fesuca rupicola, Alopecurus pratensis. 5a and 6a quadrats are different from the other sampling quadrats. These quadrats are highly covered by Calamagrostis epigeios.

On the mowed grassland, the area was also isolated in the second year (Fig. 3), which is located at the beginning of the grassland (31b-40b). The portion of grassland is highly covered by Potentilla alba and Bromus erectus. The presence of Trisetum flavescens is also considerable (Table 2).

The sampling quadrats (21b-30b) represent a well isolated group of species with connections to each other at low levels whose locations are often visited by tourists and where public programs are often organised.
In this portion of grassland, cover of the primary species of Bromus erectus and Festuca rupicola was considerably high in 2014. There is a higher level connection between the quadrats of the two mowed grasslands next to "Ösagárd", and based on the dendogram these portions of area are not clearly isolated from each other. These two portions of grassland are heterogeneous compared to the two other mowed portions of grassland. Similarities between the individual quadrats occur only at high connection levels. Similiar to the previous year, $5 \mathrm{~b}$ and $6 \mathrm{~b}$ quadrats are different from the other sampling quadrats, and the quadrats are highly covered by Calamagrostis epigeios.

Based on the DCA of the mowed sampling grasslands (Fig. 4), the following can be established concerning the analysed portions of grassland $\left(\mathrm{K} 1 \_\mathrm{a}=\right.$ 1a-10a, K2_a $=11 \mathrm{a}-20 \mathrm{a}, \mathrm{K} 3 \_\mathrm{a}=21 \mathrm{a}-30 \mathrm{a}, \mathrm{K} 4 \_\mathrm{a}=$ 31a-40a).

Three groups of the mowed grasslands can be isolated (with ellispes). An area can be isolated, which contains the quadrats of the mowed area that is located at the beginning of the meadow (31a-40a). The quadrats 


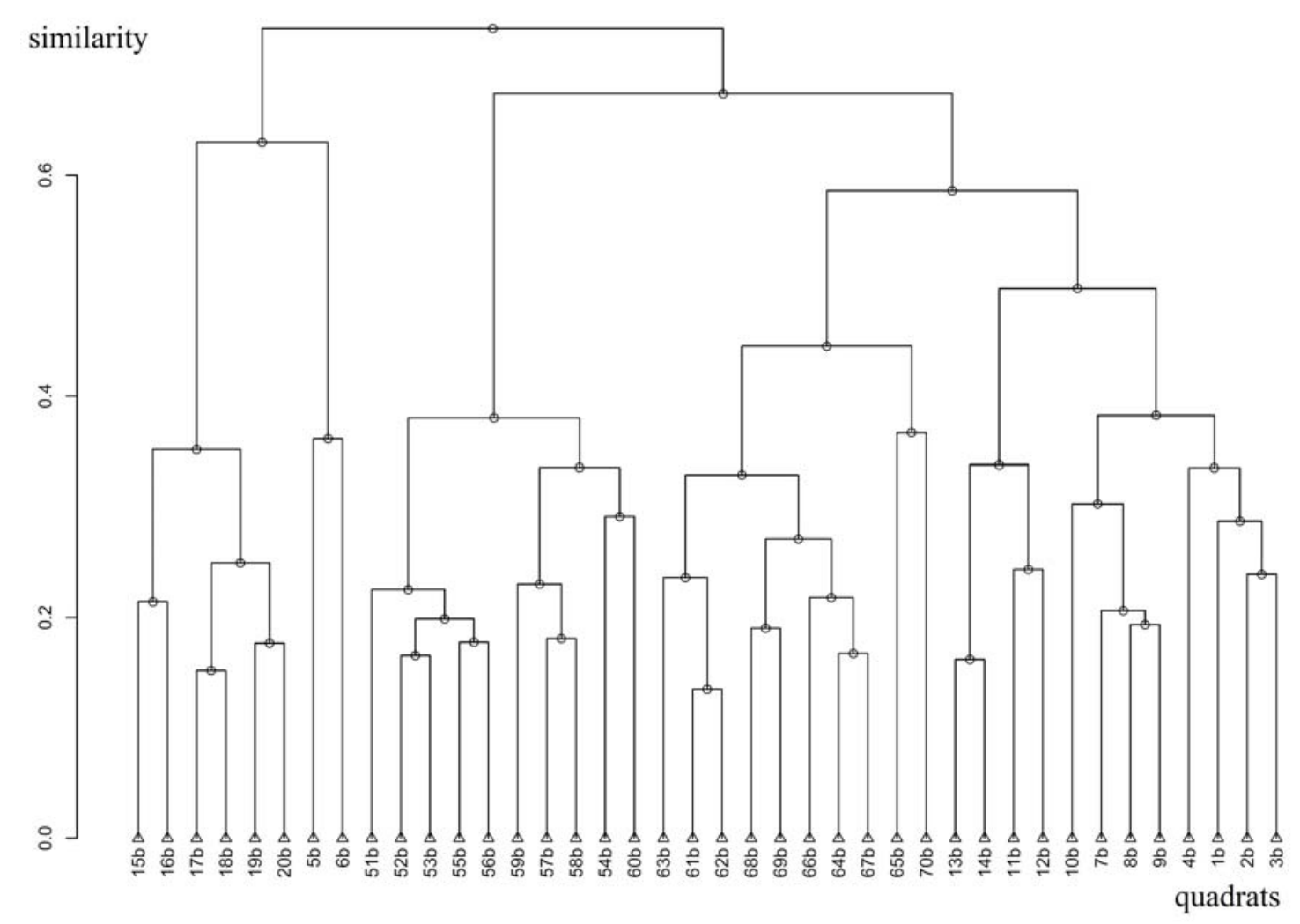

Fig. 3 Dendrogram of the sampling quadrats, 2014.

Legend: 1-10 wetter mowed meadow in the direction of Ősagárd; 11-20 dryer mowed meadow in the direction of Ősagárd; 21-30 mowed and tourist visited meadow 31-40 mowed meadow, which used to be forest; b: 2014 .

of the mowed grassland shown in the figure as effected by tourism also form an isolated group including all quadrats of the portion of the grassland (21a-30a). The third ellipse consists of the two mowed grasslands next to Ösagárd, which two portions of grassland are not clearly isolated from each other (K1_a, K2_a). These two areas are more heterogeneous than the other two mowed grasslands. The 3 quadrats of area K1_a (5a, 6a, 10a) are found outside the isolated areas, and deviate considerably from those areas.

Based on the ordination analysis, some species of the mowed grasslands next to Ösagárd (K1_a, K2_a), which characterize the isolated area are the following:

Bromus inermis, Carex praecox, Betonica officinalis, Trifolium campestre, Moenchia mantica, Cruciata laevipes, Arrhenatherum elatius, Dactylis glomerata, Knautia arvensis, Helictotrichon pubescens,
Vicia cracca, Lathyrus pratensis, Vicia hirsuta, Poa angustifolia, Festuca valesiaca.

Some species of the mowed grasslands located at the beginning of the meadow (K4_a), which characterize the isolated area: Potentilla alba, Trifolium montanum, Rhinanthus minor, Plantago lanceolata, Briza media, Salvia nemorosa, Leontodon hispidus.

The species isolated in the mowed grassland (K3_a) effected by tourism are not shown in the DCA. In accordance with the DCA, the presence of Calamagrostis epigeios promotes the isolation of the quadrats $5 \mathrm{a}, 6 \mathrm{a}$, while the presence of Brachypodium pinnatum promotes the isolation of the quadrat 10a.

Based on the DCA of the mowed grasslands with samplings in 2014 (Fig. 5), the following is established concerning the analysed portions of grassland $\left(\mathrm{K} 1 \_\mathrm{b}=1 \mathrm{~b}-10 \mathrm{~b}, \mathrm{~K} 2 \mathrm{~b}=11 \mathrm{~b}-20 \mathrm{~b}, \mathrm{~K} 3 \_\mathrm{b}=\right.$ 21b-30b, K4_b = 31b-40b). 


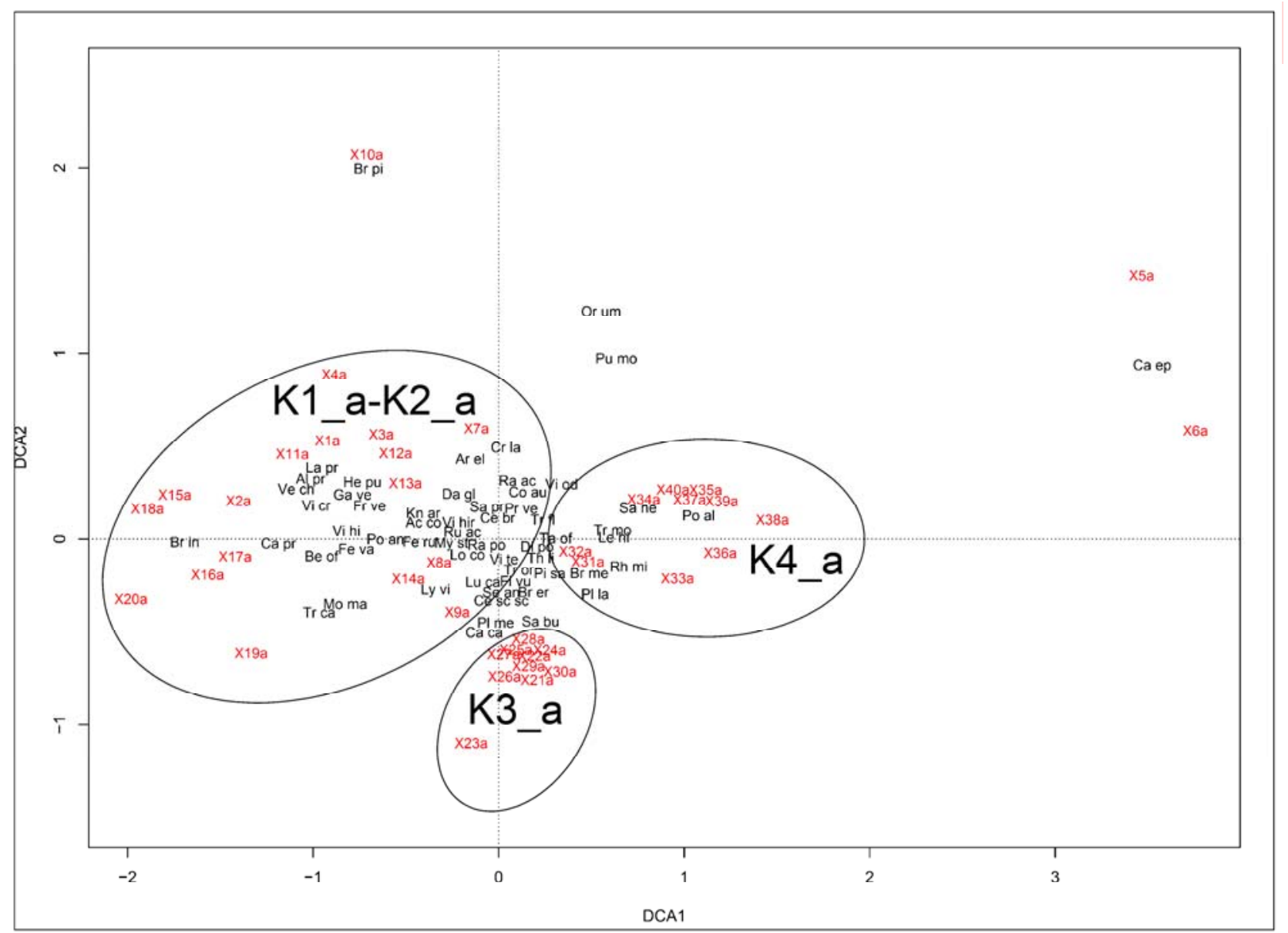

Fig. 4 Results of the DCA of mowed grasslands in 2013

Legend: Ac co: Achillea collina, Al pr: Alopecurus pratensis, Ar el: Arrhenatherum elatius, Be of: Betonica officinalis, Br pi: Brachypodium pinnatum, Br me: Briza media, $\mathrm{Br}$ er: Bromus erectus, $\mathrm{Br}$ in: Bromus inermis, Ca ep: Calamagrostis epigeios, Ca ca: Carex caryophyllea, Ca pr: Carex praecox, Ce sc sc: Centaurea scabiosa subsp. scabiosa, Ce br: Cerastium brachypetalum, Co au: Colchicum autumnale, Cr la: Cruciata laevipes, Da gl: Dactylis glomerata, Di po: Dianthus pontederae, Fe ru: Festuca rupicola, Fe va: Festuca valesiaca, Fi vu: Filipendula vulgaris, Fr ve: Fragaria vesca, Ga ve: Galium verum, He pu: Helictotrichon pubescens, Kn ar: Knautia arvensis, La pr: Lathyrus pratensis, Le hi: Leontodon hispidus, Lo co: Lotus corniculatus, Lu ca: Luzula campestris, Ly vi: Lychnis viscaria, Mo ma: Moenchia mantica, My st: Myosotis stricta, Or um: Ornithogalum umbellatum, Pi sa: Pimpinella saxifraga, Pl la: Plantago lanceolata, Pl me: Plantago media, Po an: Poa angustifolia, Po al: Potentilla alba, Pr ve: Primula veris, Pu mo: Pulmonaria mollissima, Ra ac: Ranunculus acris, Ra po: Ranunculus polyanthemos, Rh mi: Rhinanthus minor, Ru ac: Rumex acetosa, Sa ne: Salvia nemorosa, Sa pr: Salvia pratensis, Sa bu: Saxifraga bulbifera, Se an: Seseli annuum, Ta of: Taraxacum officinale, Th li: Thesium linophyllon, Tr or: Tragopogon orientalis, Tr ca: Trifolium campestre, Tr mo: Trifolium montanum, Tr fl: Trisetum flavescens, Ve ch: Veronica chamaedrys, Vi cr: Vicia cracca, Vi hi: Vicia hirsuta, Vi te: Vicia tenuifolia, Vi hir: Viola hirta, Vi od: Viola odorata

K1_a: 1-10 wetter mowed meadow in the direction of Ösagárd; K2_a: 11-20 dryer mowed meadow in the direction of Ősagárd; K3_a 21-30 mowed and tourist visited meadow; K4_a: 31-40 mowed meadow, which used to be forest, a: 2013

Four groups of the mowed grassland can be isolated (with irregular forms), however, this isolation is not entirely clear as minimum 1-2 quadrats occur in an other isolated group in which they were not expected. An area can be isolated, where the quadrats of the mowed area located at the beginning of the meadow are found $(31 b-40 b)$. The figure shows that the quadrats of the mowed grassland effected by tourism also form a separate group, which includes the quadrats $21 b-28 b$ of the portion. The third group consists of 


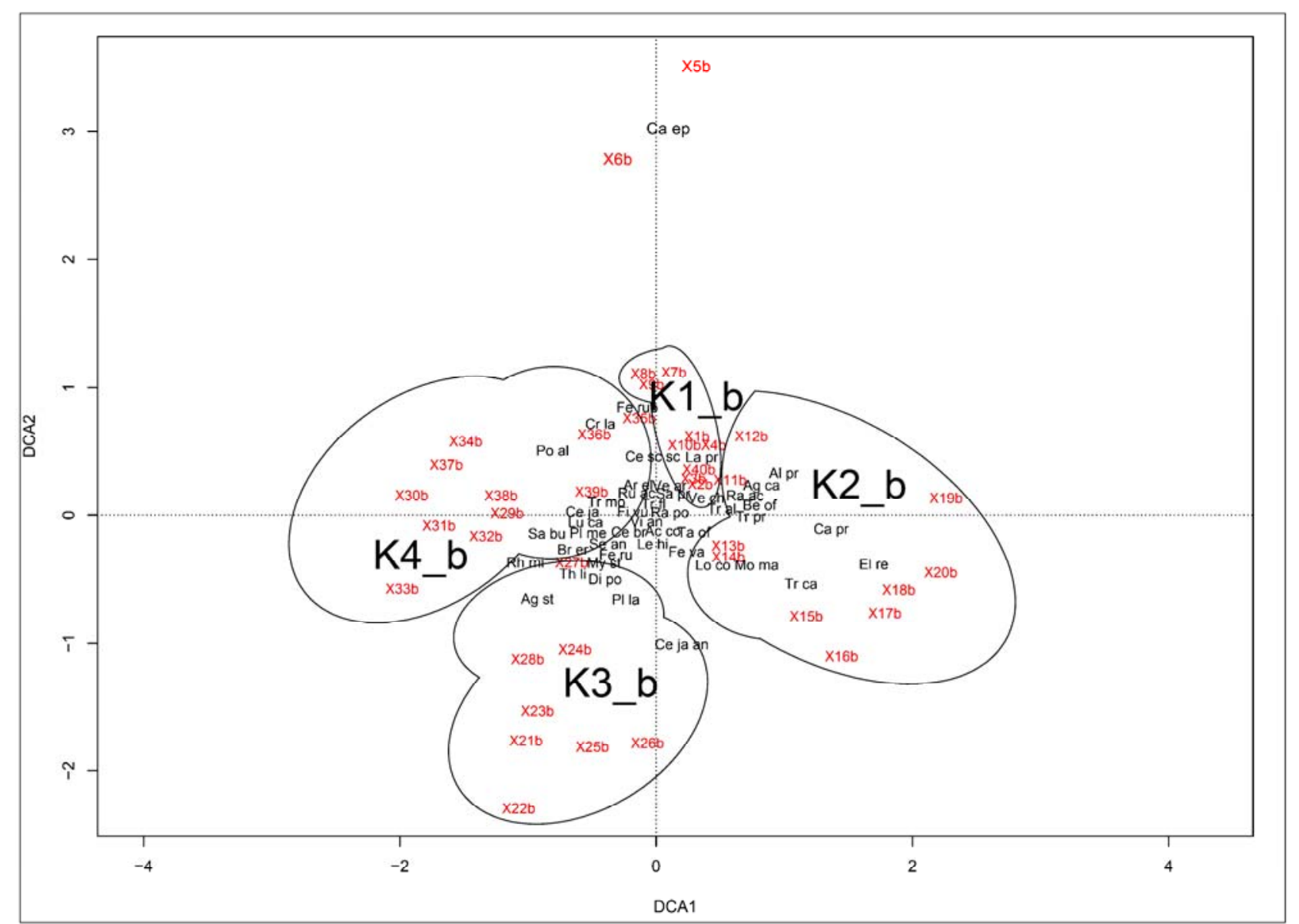

Fig. 5 Results of the DCA of mowed grasslands in 2014

Legend: Ac co: Achillea collina, Ag ca: Agrostis capillaris, Ag st: Agrostis stolonifera, Al pr: Alopecurus pratensis, Ar el: Arrhenatherum elatius, Be of: Betonica officinalis, $\mathrm{Br}$ er: Bromus erectus, $\mathrm{Ca}$ ep: Calamagrostis epigeios, Ca pr: Carex praecox, Ce ja: Centaurea jacea, Ce ja an: Centaurea jacea subsp. angustifolia, Ce sc sc: Centaurea scabiosa subsp. scabiosa, Ce br: Cerastium brachypetalum, Cr la: Cruciata laevipes, Di po: Dianthus pontederae, El re: Elymus repens, Fe rub: Festuca rubra, Fe ru: Festuca rupicola, Fe va: Festuca valesiaca, Fi vu: Filipendula vulgaris, La pr: Lathyrus pratensis, Le hi: Leontodon hispidus, Lo co: Lotus corniculatus, Lu ca: Luzula campestris, Mo ma: Moenchia mantica, My st: Myosotis stricta, Pl la: Plantago lanceolata, Pl me: Plantago media, Po al: Potentilla alba, Ra ac: Ranunculus acris, Ra po: Ranunculus polyanthemos, Rh mi: Rhinanthus minor, Ru ac: Rumex acetosa, Sa pr: Salvia pratensis, Sa bu: Saxifraga bulbifera, Se an: Seseli annuum, Ta of: Taraxacum officinale, Th li: Thesium linophyllon, $\operatorname{Tr}$ al: Trifolium alpestre, $\operatorname{Tr}$ ca: Trifolium campestre, $\operatorname{Tr}$ mo: Trifolium montanum, $\operatorname{Tr}$ pr: Trifolium pratense, Tr fl: Trisetum flavescens, Ve ar: Veronica arvensis, Ve ch: Veronica chamaedrys, Vi an: Vicia angustifolia

K1_b: 1-10 wetter mowed meadow in the direction of Ősagárd; K2_b: 11-20 dryer mowed meadow in the direction of Ösagárd; K3_b 21-30 mowed and tourist visited meadow; K4_b: 31-40 mowed meadow, which used to be forest, b: 2014

the mowed grassland far from Ösagárd, which includes all quadrats of the portion (11b-20b). The fourth portion (1a-4a, 7a-10a) consists of the quadrats of the mowed area next to Ösagárd. Two quadrats of this area $(5 b, 6 b)$ are found outside the isolated groups and deviate considerably from those.

Based on the ordination analysis, some species of the mowed grasslands far from Ösagárd which characterize the isolated area are the following $\left(\mathrm{K} 2 \_b\right)$ : Alopecurus pratensis, Carex praecox, Elymus repens, Trifolium campestre. The species that characterizes the mowed grassland next to Ösagárd is the Lathyrus pratensis.

On the grassland effected by tourism (K3_b), there are more extensive covers of Agrostis stolonifera, Plantago lanceolata, Thesium linophyllon, Centaurea 
jacea subsp. angustifolia. In the mowed grassland located at the beginning of the meadow (K4_b), the following species occur at higher rates: Potentilla alba, Trifolium montanum, Saxifraga bulbifera, Rhinanthus minor, Plantago media, Luzula campestris, Festuca pratensis. In accordance with the DCA, the isolation of quadrats $5 \mathrm{~b}$ and $6 \mathrm{~b}$ is caused by Calamagrostis epigeios.

We defined the amount of rainfall for the area with interpolation based on the National Weather Service' database, taking into account the measurements of the nearest rain gauge stations. The precipitation difference of the two surveyed years can be seen in the figure below (Fig. 6). The figure clearly shows that the increase of precipitation in 2014, in the growing season is significant.

The second year was much rainier, thus the diversity was considerably increased in all surveyed areas. The Shannon's diversity record on areas effected by tourism is the lowest as an avarage in both years of the survey, while the diversity of the area located at the beginning of the meadow functioning as forest area for a long time hardly differs from the diversity of the other two mowed areas (Figs. 7 and 8).

Based on the analysis of humidity preferences it is evident that in the rainier year in the portion of the wetter mowed grassland next to Ösagárd more species were categorized as moderately dry or moderately moist, and in the portion of the dryer mowed grassland far from Ösagárd were more species categorized as dry. These two areas had miner deviation in the rainier year. In the year with less rain, the portion of grassland effected meaningfully by tourism has very similar characteristics to the portion of grassland located at the beginning of the meadow. In 2014, these two portions of grassland differed considerably from each other: while a great number of species with higher humidity preference occurred at the beginning of the meadow, the number of species categorized as moderately dry highly increased on the area effected meaningfully by tourism (Figs. 9 and 10).

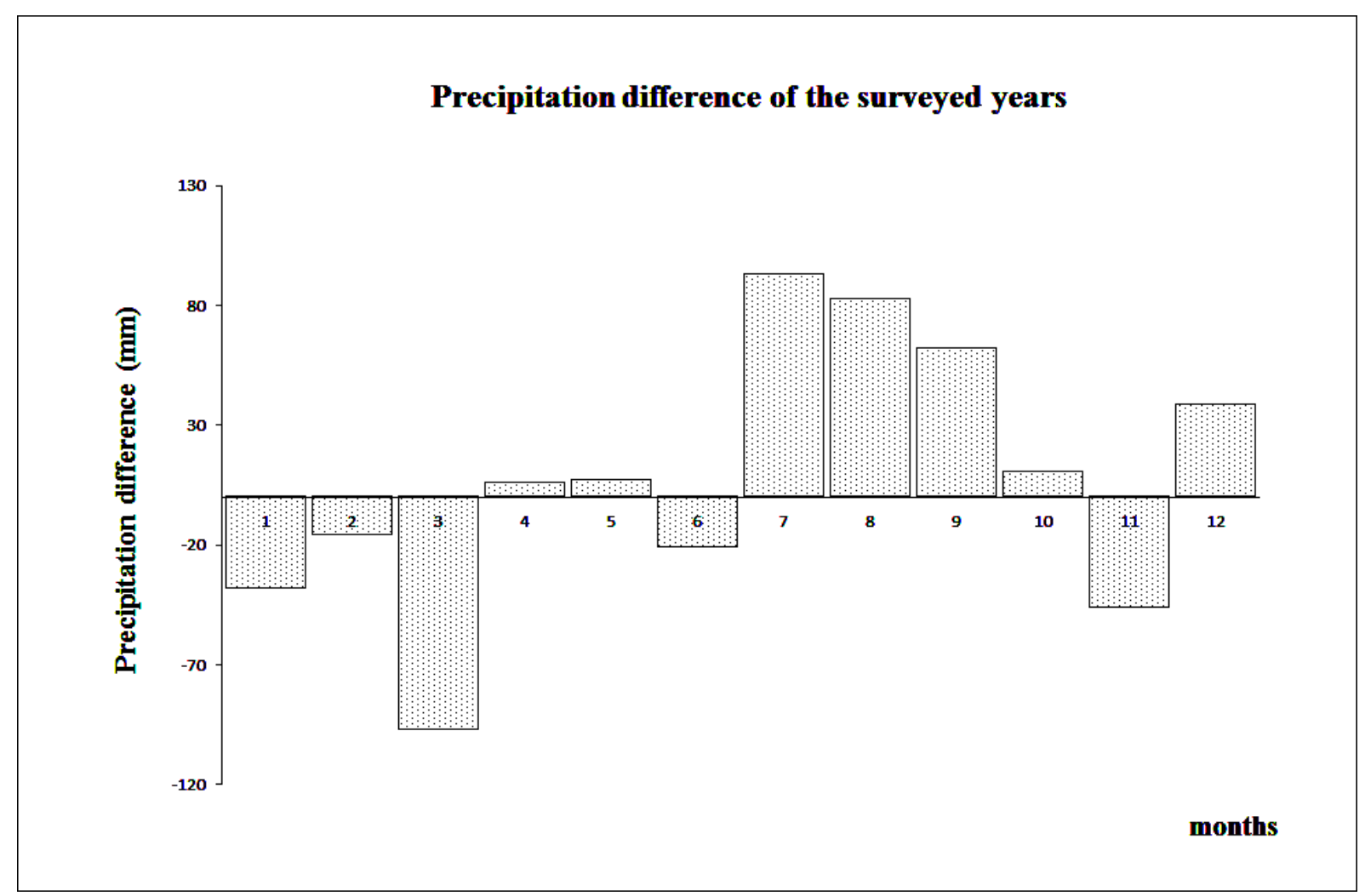

Fig. 6 Precipitation difference of the surveyed years. 


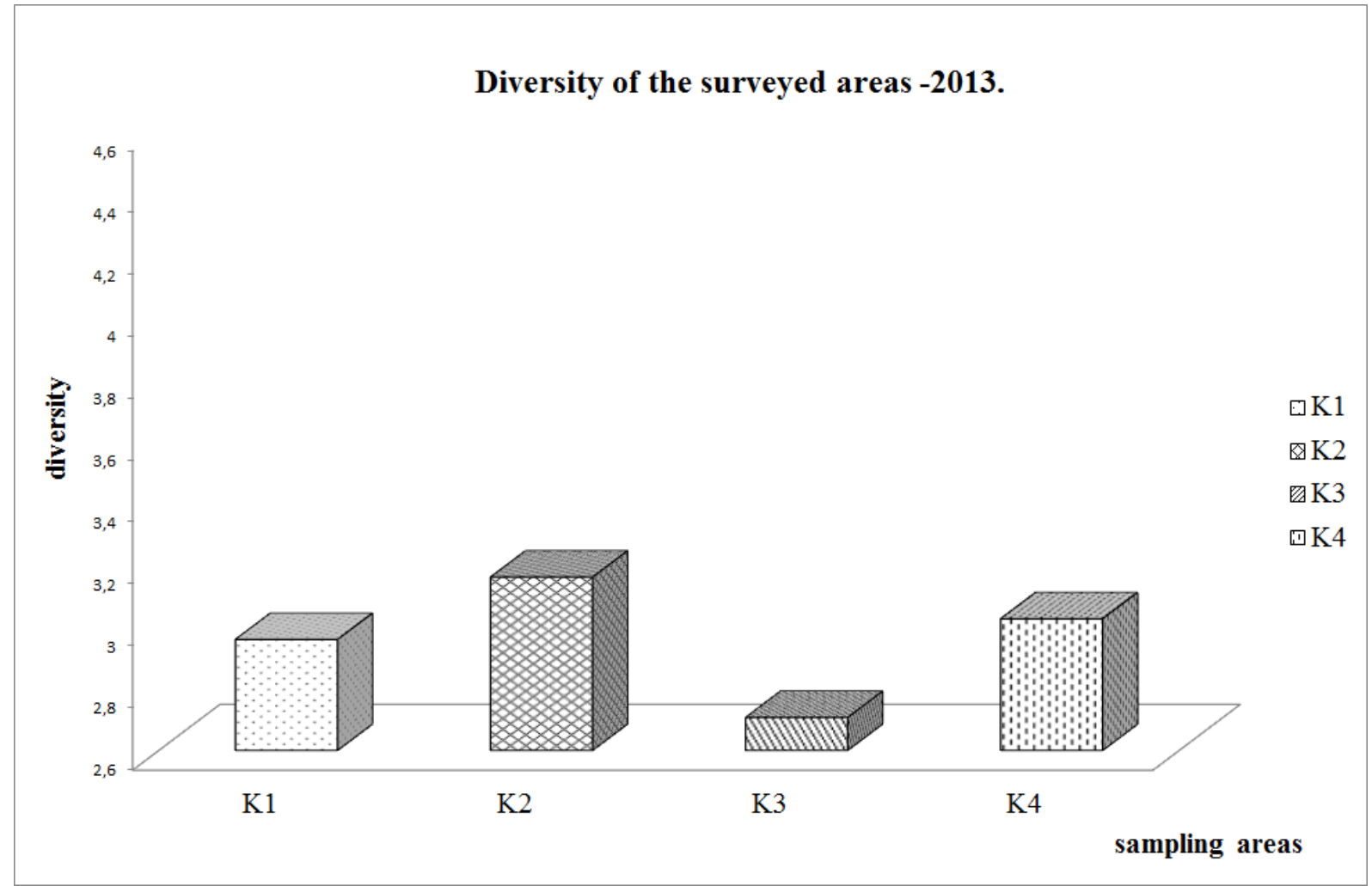

Fig. 7 Diversity of the surveyed areas, 2013.

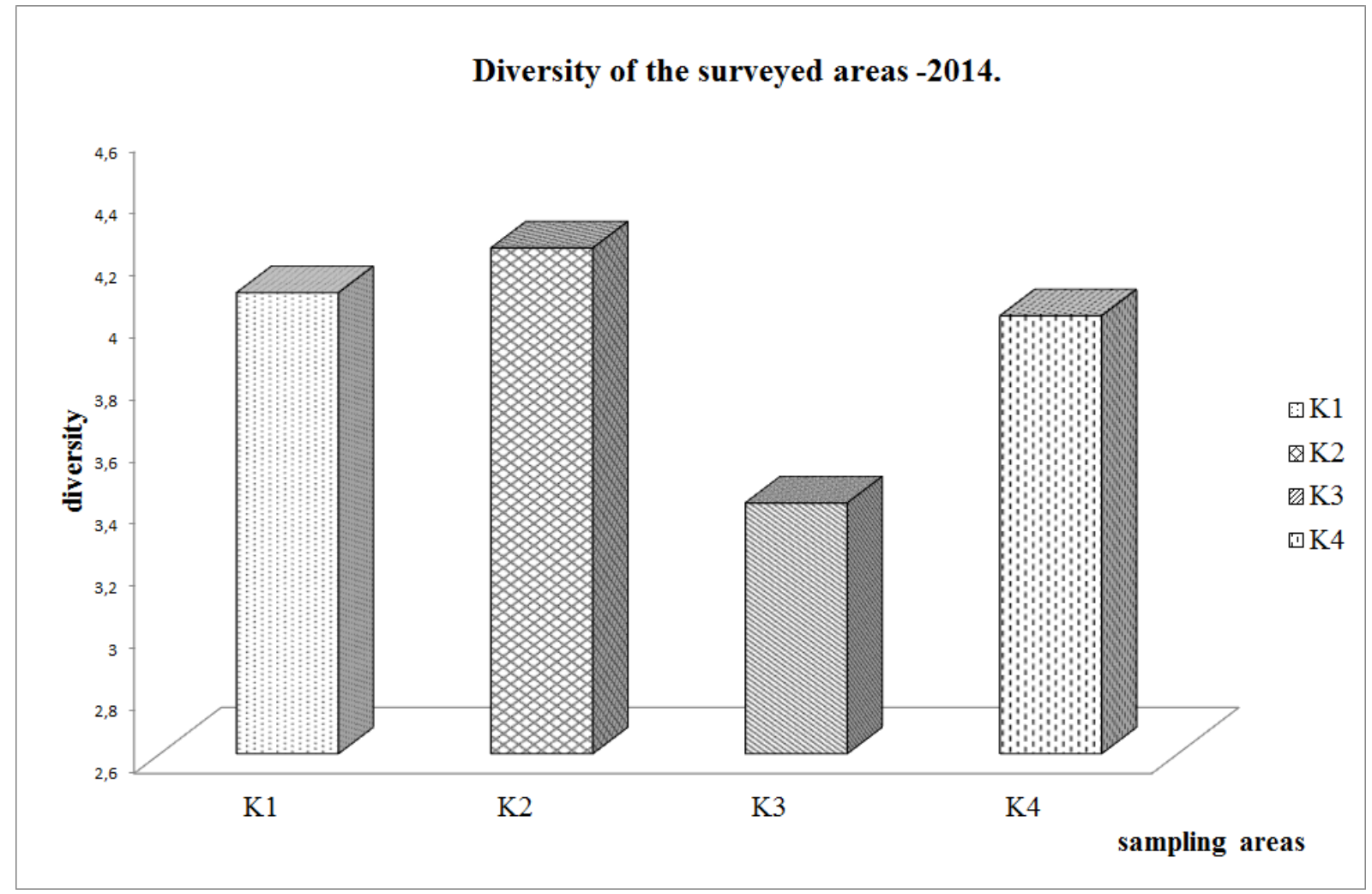

Fig. 8 Diversity of the surveyed areas, 2014. 


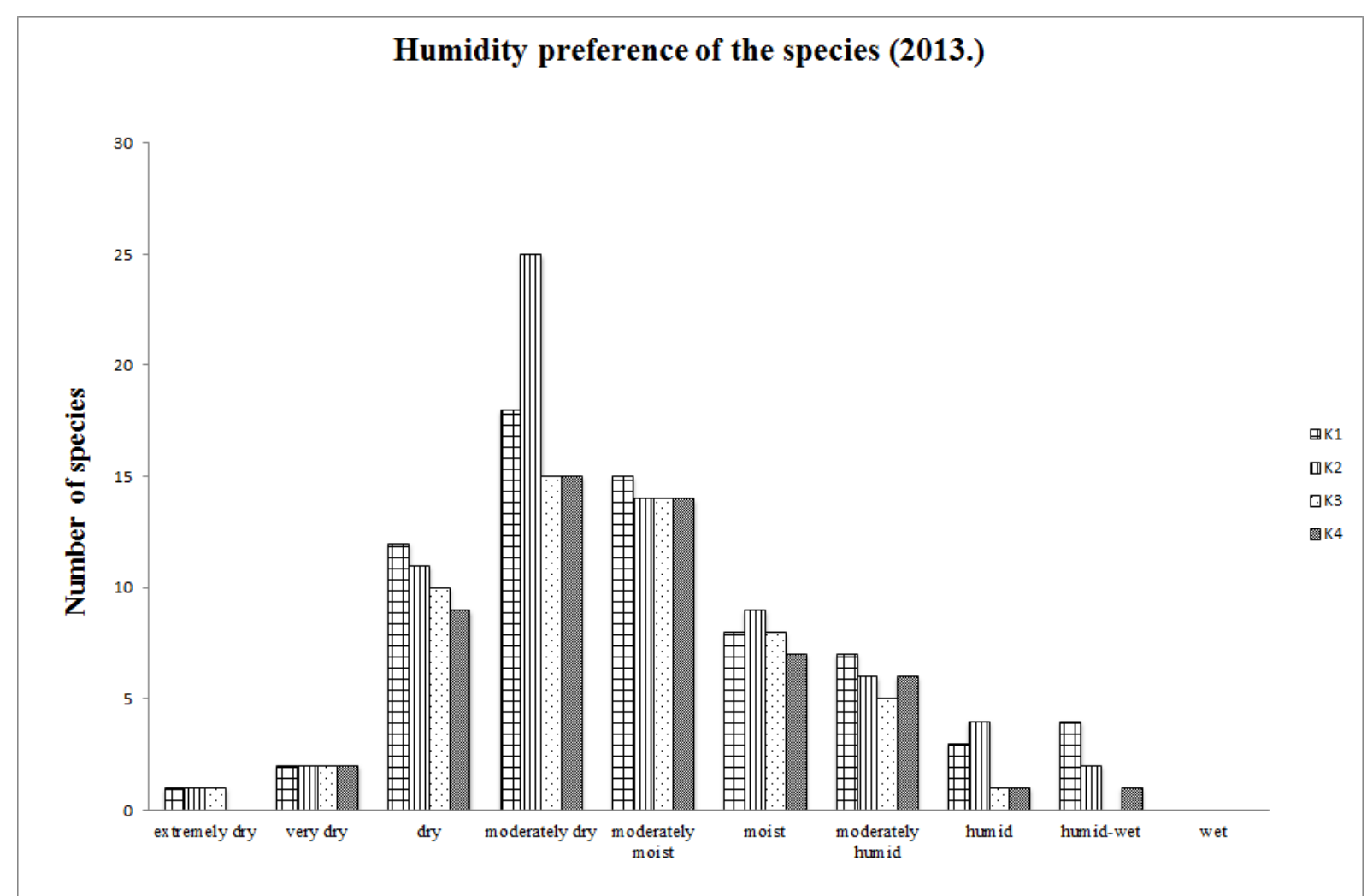

Fig. 9 Humidity preference of the plant species, 2013.

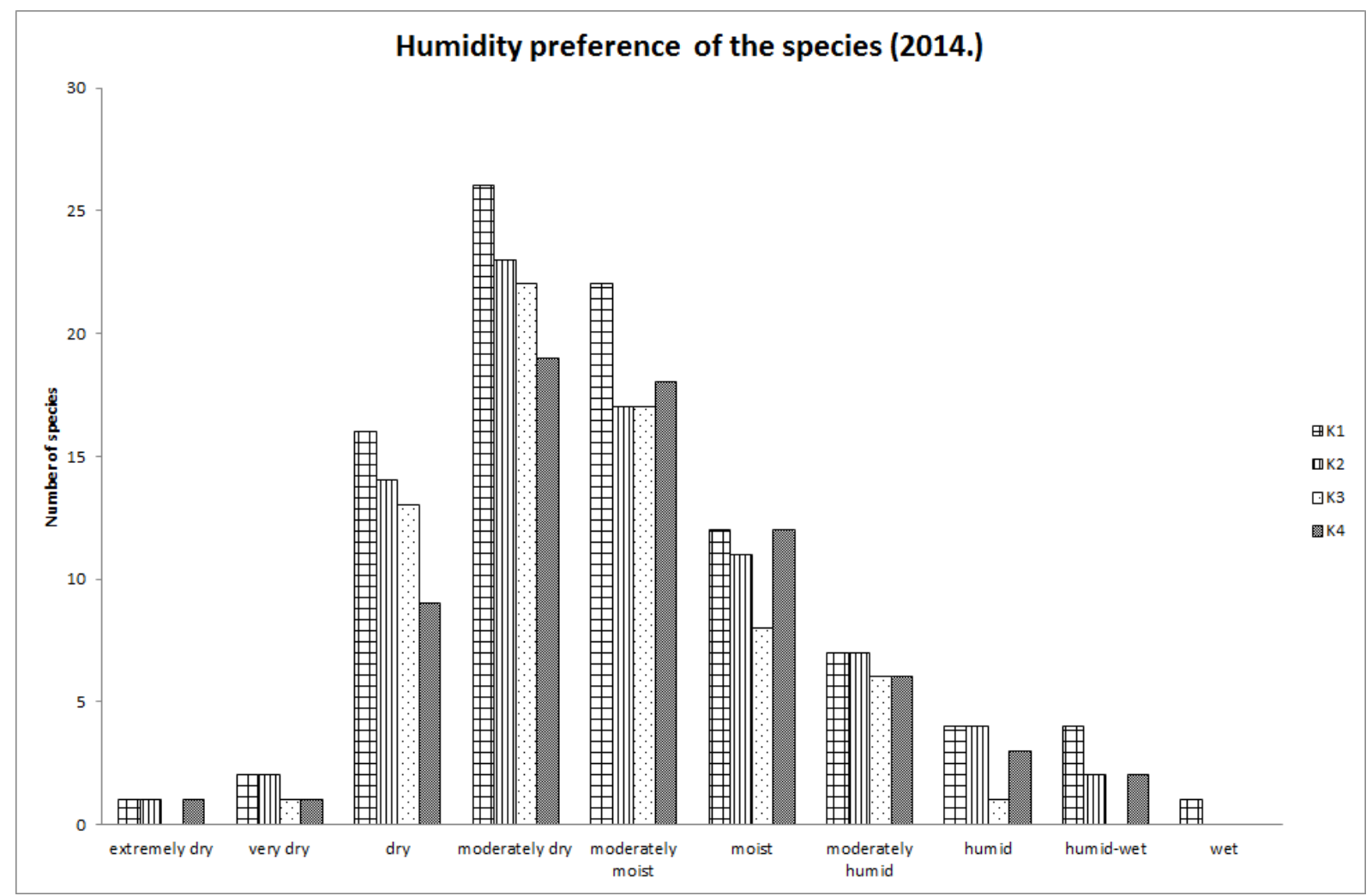

Fig. 10 Humidity preference of the plant species, 2014. 


\section{Conclusions}

From a nature conservation point of view, it is favourable that the number of species of Potentilla alba occurring in the area is high. It is a special plant species with low stress resistance [40]. However, due to tourism, it occurs even less in the area and instead, Bromus erectus becomes dominant. It might be also due to tourism that Bromus erectus not only displaces previous species, but also achieves a less dominant cover of species. The plant species whose covers are more extensive in areas not effected by tourism, for example Alopecurus pratensis, Galium verum, Carex praecox, Trisetum flavescens-occur less frequently in areas effected by tourism. The species reacts first to the changed conditions not with disappearence but with a the change in relation to dominance, as has been already supported by other survey [41].

The ordination analysis shows that the composition of species considerably differs with the portions of land cultivated in different ways. In the portion of grassland effected by tourism, the number of species characterising the individual area is low, which is more characteristic in years with less rain, when the diversity of species is reduced. The change of the cover values affects not only the occurrance of the dominant species but of the species with less cover. The decrease of diversity, the change of plantcover, the decrease of number of sensitive species as a result of tourism are registered all over the world [42, 43].

The Shannon's diversity records show that due to human presence and trampling the diversity of the species is reduced. The diversity of species is considerably low in years with less rain. In years with more rain the diversity of species is considerably higher, however, the difference in diversity between the surveyed areas is much increased. All these examples draw attention to the important role of environmental factors alongside the human factors [44]. The water reserve also influences the productivity of grasslands and water has primary importance in the structure of plant communities [45].

According to the survey, on the two areas not effected by tourism, in the rainier year the difference between the humidity preference of the plant species occurred on the dry areas and on the less dry areas became similar. In the rainier year, the differences increased between two portions of grassland with similar humidity preferences but different land use. On areas not effected by tourism, there were more species with higher humidity preferences occurred in rainier year, however, this tendency could not be observed in the rainier year on areas effected by tourism. The areas effected by tourism may react less flexibly to the change in rain conditions.

It can be said based on our analysis, that the surveyed semi-dry grasslands in the Pannon mountains are extremely rich in species and therefore proper grassland management plans should be drawn up. To preserve grasslands of high natural value, the impacts of the environmental factors should also be considered in addition to becoming acquainted with the history and present conditions of the landscape use $[36,46-50]$.

\section{References}

[1] Luick, R. 1998. "Ecological and Socio-Economic Implications of Livestock-Keeping Systems on Extensive Grasslands in South-Western Germany." Journal of Applied Ecology 35: 979-82.

[2] Zervas, G. 1998. "Quantifying and Optimizing Grazing Regimes in Greek Mountain Systems.” Journal of Applied Ecology 35: 983-6.

[3] Dullinger, S., Dirnböck, T., and Grabherr, G. 2003. "Patterns of Shrub Invasion into High Mountain Grasslands of the Northern Calcareous Alps, Austria." Arctic, Antarctic, and Alpine Research 35 (4): 434-41.

[4] Sebastià, M. T., de Bello, F., Puig, L., and Taull, M. 2008. "Grazing as a Factor Structuring Grasslands in the Pyrenees." Applied Vegetation Science 11: 215-22.

[5] Penksza, K., Szentes, S., Loksa, G., Dannhauser, C., and Házi, J., 2010. “A legeltetés hatása a gyepekre és természetvédelmi vonatkozásai a Tapolcai- és a Káli-medencében." (Effects of Grazing on Grassland, and Nature Conservation Aspects in the Tapolcai and Káli basins.) Természetvédelmi Közlemények 16: 25-49. 
[6] Penksza K., Házi J., Tóth A., Wichmann B., Pajor F., Gyuricza Cs., Póti P., Szentes Sz. 2013. "Eltérő hasznosítású szürkemarha legelő szezonális táplálóanyag tartalom alakulás, fajdiverzitás változása és ennek hatása a biomassza mennyiségére és összetételére nedves pannon gyepekben." (Cut Moving and Grazing Effects With Grey Cattle on Plant Species Composition in Case of Pannon Wet Grasslands.) Növénytermelés 62 (1): 73-94.

[7] Házi J., Bartha S., Szentes Sz., Wichmann B., and Penksza, K. 2011. "Seminatural Grassland Management by Mowing of Calamagrostis Epigejos in Hungary." Plant Biosystems 145: 699-707.

[8] Házi, J., Penksza, K., Bartha, S., Hufnagel, L., Tóth, A., Gyuricza, Cs., Szentes, Sz. 2012. "Cut Mowing and Grazing Effects With Grey Cattle on Plant Species Composition in Case of Pannon Wet Grasslands." Applied Ecology and Enviromental Research 10: 223-31.

[9] Szentes, Sz., Dannhauser, C., Coetzee, R., and Penksza, K, 2011. "Biomass Productivity, Nutrition Content and Botanical Investigation of Hungarian Grey Cattle Pasture in Tapolca Basin." AWETH 7 (2): 180-98.

[10] Szentes, Sz., Dannhauser, C., Coetzee, R., Penksza, K. 2011. "Biomass Productivity, Nutrition Content and Botanical Investigation of Hungarian Grey cattle Pasture in Tapolca Basin." AWETH 7 (2): 180-98.

[11] Zimmermann, Z., Szabó, G., Bartha, S., Szentes, Sz., and Penksza, K. 2011. "Juhlegeltetés hatásainak természetvédelmi célú vizsgálata legelt és művelésből kivont gyepek növényzetére. (Review of the Effects of Sheep Pasturing on Grazed and Arable Lands from Nature Conservation Aspect.)" AWETH 7 (3): 234-62.

[12] Nagy G. 2008. “A gyephasználati lehetőségek sokoldalúsága. [Diverse Use of Grassland.]" Gyepgazdálkodási Közlemények 6: 5-7.

[13] Kenéz, Á., Szemán, L., Szabó, M., Saláta, D., Malatinszki, Á., Penksza, K., and Breuer, L. 2007. "Természetvédelmi célú gyephasznosítási terv a pénzesgyőr-hárskúti hagyásfás legelő élőhely védelmére. (Pasture Management Plan Aiming Nature Conservation for the Portection of the Wooded Pasture between Pénzesgyőr and Hárskút.)" Tájökológiai Lapok 5: 35-41.

[14] Habel, J. C., Dengler, J., Janišova, M., Török, P., Wellstein, C., Wiezik, M. 2013. "European Grassland Ecosystems: Threatened Hotspots of Biodiversity." Biodiversity and Conservation 22: 2131-8.

[15] Houghton, J., Ding, Y., Griggs, D. J., Noguer, M., Van Der Linden, P. J., Dai, X., Maskell, K., and Johnson, C. A. (eds). 2001. Climate Change 2001: The Scientific Basis. Cambridge, UK: Cambridge University Press.
[16] Drewitt, A. L. 2007. "Birds and Recreational Disturbance." Ibis 149: 1-2.

[17] Kaligarič, M., Culiberg, M., and Kramberger, B. 2006. "Recent Vegetation History of the North Adriatic Grasslands: Expansion and Decay O Fan Antropogenic Habitat." Folia Geobotanica 41: 241-58.

[18] Penksza, K., Tasi, J., Szentes, Sz., Centeri, Cs. 2008. “Természetvédelmi célú botanikai, takarmányozástani és talajtani vizsgálatok a Tapolcai és Káli-medence szürkemarha és bivaly legelöin. [Botanical, Fodder and Soil Investigations Aiming at the Conservation of Nature on the Grey Cattle Pastures of Tapolcai And KÁLi Basins. Publications of Grassland Management.]" Gyepgazdálkodási Közlemények 6: 47-53.

[19] Török, P., Kelemen, A., Valkó, O., Deák, B., Lukács, B., and Tóthmérész, B. 2011. "Lucerne dominated fields recover naitve grass diversity without intensive management actions." Journal of Applied Ecology 48: 257-264.

[20] Szentes, Sz., Tasi, J., Wichmann, B., and Penksza, K. 2009. Botanikai és gyepgazdálkodási vizsgálatok 2008 . évi eredményei a badacsonytördemici szürkemarha legelön. [The Results of Bothanial and Grassland Management Analyses as of 2008 on the Gey Cattle Pasture in Badacsonytördemic.]" Gyepgazdálkodási Közlemények 7: 73-8.

[21] Valkó, O., Török, P., Matus, G., and Tóthmérész, B. 2012. "Is Regular Mowing the Most Appropriate and Cost-Effective Management Maintaining Diversity and Biomass of Target Forbs in Mountain Hay Meadows?" Flora 207 (4): 303-9.

[22] Kelemen, A., Török, P., Valkó, O., Deák, B., Miglécz, T., Tóth, K., Ölvedi, T., and Tóthmérész, B. 2014. "Sustaining Recovered Grasslands in not Likely without Proper Management:Vegetation Changes and Large-Scale Evidences after Cessation of Mowing." Biodiversity \& Conservation. 23: 741-51.

[23] Whittaker, R. H., and Levin, S. A. 1977. "The Role of Mosaic Phenomena in Natural Communities." Theoretical Populaion Biology 12: 117-39.

[24] Besnyői, V., Szerdahelyi, T., Bartha, S., and Penksza, K. 2012. "Kaszálás felhagyásának kezdeti hatása nyugat-magyarországi üde gyepek fajkompozíciójára. [The initial effects of the abandoning of haymaking on the composition of species of the green grasslands in Western Hungary.]" Gyepgazdálkodási Közlemények 10 (1-2): 13-20.

[25] Penksza, K., Tasi, J., Szabó, G., Zimmermann, Z., and Szentes, Sz. 2009. "Természetvédelmi célú botanikai és takarmányozástani vizsgálatok adatai Káli-medencei juhlegelőhöz. [Data of botanical and fodder investigations 
aiming at nature conservation for the sheep pastures of the Káli basin.] " Gyepgazdálkodási Közlemények 7: 51-58.

[26] Penksza, K., Szentes Sz., Centeri Cs., and Tasi, J. 2009. "Juhlegelő természetvédelmi célú botanikai, takarmányozástani és talajtani vizsgálata a Káli-medencében [Botanical, Fodder and Soil Investigations Aiming at Nature Conservation of Sheep Pastures in the Káli basin] I. Animal Welfare, Etológia És Tartástechnológia 5 (1): 49-62.

[27] Penksza, K., Szentes, Sz., Házi, J., Tasi, J., Bartha, S., and Malatinszky, Á. 2009. "Grassland Management and Nature Conservation in Natural Grasslands of the Balaton Uplands National Park, Hungary. Grassland Science in Europe. Alternative Function of Grassland." In International Occasional Symposium European Grassland Federation. Brno Czech Republik 7-9. September 2009, pp. 512-5.

[28] Stroh M., Storm C., Zehm A., Schwabe A. 2002. "Restorative Grazing as A Tool for Directed Succession with Diaspore Inoculation: The Model of Sand Ecosystems." Phytocoenologia 32: 595-625.

[29] Szabó, G., Zimmermann, Z., Szentes, Sz., Sutyinszki, Zs., and Penksza, K. 2010/11. “Természetvédelmi és gyepgazdálkodási vizsgálatok a Dinnyési-fertő gyepeiben. [Nature Conservation and Grassland Management Surveys on the Grasslands of Dinnyési-fertö.]" Gyepgazdálkodási Közlemények 8 (2): 31-38.

[30] Bissels S., Donath T. W., Hölzel N., Otte A. 2006. "Effects of different mowing regimes on seedling recruitment in alluvial grasslands." Basic and Applied Ecology 7: 433-42.

[31] Deák B., Valkó O., Schmotzer A., Kapocsi I., Tóthmérész B., and Török P. 2012. "Gyepek égetésének természetvédelmi megítélése-probléma vagy gyepkezelési alternatíva? [Judging Grassland Firing from Nature Conservation Aspect-Problem or Grassland Management Alternative?]" Tájökológiai Lapok 10 (2): 287-303.

[32] Kleijn, D., and Sutherland, W. J. 2003. "How Effective are European Agri-Environment Schemes in Conserving and Promoting Biodiversity?" Journal of Applied Ecology 40: 947-69.

[33] Dövényi Z. (ed) 2010. "Magyarország kistájainak katasztere. [Cadastre of the Small Regions of Hungary.]" Budapest: MTA FKI.

[34] Rév Sz., Marticsek J., and Fülöp Gy. 2008. “Természetvédelmi Szempontú Gyephasznosítás. [Grassland Utilisation from Nature Concervation Aspect]". Budapest: Duna-Ipoly Nemzeti Park Igazgatóság
[35] Kertész Á. 1988. A Dunakanyar-hegyvidék természeti környezetpotenciáljának mezögazdasági és idegenforgalmi szempontú értékelése. [Evaluation of the Potential Environmental Improvement of the Mountains along Dunakanyar from agricultural and touristic aspects.] Budapest: MTA Földrajztudományi Kutatóintézet.

[36] Pintér B., Tímár G. (eds) 2010. “A Naszály természetrajza. [A natural history of Mt Naszály]" Budapest: Duna-Ipoly Nemzeti Park Igazgatóság

[37] Király, G. (ed) 2009. Új magyar füvészkönyv Magyarország hajtásos növényei Határozókulcsok [New Hungarian Herbal Invasive Plants in Hungary. Identificatin keys.] Jósvafö: Aggteleki Nemzeti Park Igazgatóság.

[38] Király, G., Virók V., Molnár V. A. (eds) 2011. “Új magyar füvészkönyv Magyarország hajtásos növényei Ábrák [New Hungarian Herbal Invasive plants in Hungary. Figures]" Jósvafő: Aggteleki Nemzeti Park Igazgatóság.

[39] Borhidi A. 2003. Magyarország növénytársulásai. [The phytocoenoses of Hungary]. Budapest: Akadémiai Kiadó.

[40] Horváth F., Dobolyi Z. K., Morschhauser T., Lőkös L., Karas L., and Szerdahelyi, T. 1995. "Flóra adatbázis 1.2. Taxonlista és attribútum állomány. [Data Base of Flora 1.2. Taxonomy List and Attributes.]" MTA ÖBKI. Vácrátót.

[41] Pavlů, L., Pavlů, V., Gaislera, J., Hejcman, M., and Mikulka, J. 2011. "Effect of Long-Term Cutting Versus Abandonment on the Vegetation of A Mountain Hay Meadow (Polygono-Trisetion) in Central Europe." Flora 206: $1020-9$

[42] Podani J. 1997. "Bevezetés a többváltozós biológiai adatfeltárás rejtelmeibe. [Introduction to the Exploration of Multivariate Biological Data.]" Budapest: Scientia Kiadó.

[43] Le, C., Ikazaki, K., Kadono, A., and Kosaki. T. "Grassland Degradation Caused by Tourism Activities in Hulunbuir, Inner Mongolia, China. " Earth and Environmental Science 18 (2014) 1-7.

[44] Grabherr, G. 1982. "The Impact of Trampling by Tourists on A High Altitudinal Grassland in the Tyrolean Alps, Austria." Vegetatio 48 (3): 209-17.

[45] Stampfli, A. 1995. "Species Composition and Standing Crop Variation in An Unfertilized Meadow and Its Relationship to Climatic Variability During Six Years." Folia Geobotanica Phytotaxonomica 30: 117-130

[46] Barcsák Z. 1989. "Gyeptermesztés és hasznosítás." [Grass Cultivation and Utilization] Gödöllö: GATE

[47] Bartholy, J., Pongrácz, R., Nagy, J., Pierczka, I., and Hufnagel, L. 2012. "Regional Climate Change Impacts 
on Wild Animals' Living Territory in Central Europe" Applied Ecology and Environmental Research 10 (2): 107-120.

[48] Gustavsson, E., Lennartsson, T., and Emanuelsson M. 2007. "Land Use More than 200 Years ago Explains Current Grassland Plant Diversity in A Swedish Agricultural Landscape." Biological Conservation 138: 47-59.

[49] Catorci, A., Cesaretti, S., Gatti, R., and Ottaviani, G.
2011. "Abiotic and Biotic Changes due to Spread of Brachypodium Genuense (DC.) Roem.\& Schult." In Sub-Mediterranean Meadows. Community Ecology 12: 117-25.

[50] Galvánek, D., and Lepš, J. 2009. "How do Management and Restoration Needs of Mountain Grasslands Depend on Moisture Regime? Experimental Study from North-Western Slovakia (Western Carpathians)." Applied Vegetation Science 12: 273-82. 